\title{
Translation ethics
}

\section{Chesterman, Andrew Peter Clement}

John Benjamins

2018

pÿChesterman , A P C 2018 , Translation ethics . in L D hulst \& Y Gambier (eds), A History of Modern Translation Knowledge : Sources, concepts, effects . Benjamins Translation Library , no. 142 , John Benjamins , Amsterdam , pp. 443-448 . https://doi.org/10.1075/btl.142.62che

http://hdl.handle.net/10138/237359

https://doi.org/10.1075/btl.142.62che

unspecified

acceptedVersion

Downloaded from Helda, University of Helsinki institutional repository.

This is an electronic reprint of the original article.

This reprint may differ from the original in pagination and typographic detail.

Please cite the original version. 


\section{TRANSLATION ETHICS}

Andrew Chesterman

University of Helsinki, Finland

[2018b In L. D'hulst and Y. Gambier (eds), A History of Modern Translation Knowledge. Sources, concepts, effects. Amsterdam: Benjamins, 443-448.]

Keywords: ethics, fidelity, alterity, loyalty, responsibility

\section{Basic issues}

"Translation ethics" (or "translator ethics") refers to the set of accepted principles according to which translation should be done (and, mutatis mutandis, interpreting), and hence the norms governing what translations should be like. As translating is a form of linguistic behaviour, translation ethics can also be seen as embedded in an ethics of language or communication more generally.

In philosophical theories of ethics two broad types of theory are distinguished. One is utilitarian or consequentialist, where the ethical status of an act is determined by its results. The other is contractual, or duty-based: an ethical act is one that conforms to a contract. In translation ethics, we find elements of both these types of theory.

Since ideas about ethics have to do with our understanding of the concept "good", translation ethics overlaps with issues of quality. Some recent work has aimed to expand the notion of "translation quality" to include ethical aspects of a translator's working conditions, bridging the difference between textual and human relations. 
One focus in contemporary Translation Studies is on the translators/interpreters themselves, rather than the texts they produce. If we want to explore how all kinds of translation agents work, what motivates them, how they make decisions, then we must also take account of axiological issues - and thus of ethics, both professional and personal. Debates about translation ethics have started with the question "how should one translate?", but then other questions also arise: "should one translate this?" And even: "how can one make the world a better place by translating?"

\section{Evolution and variation}

In the Western tradition, translation/interpreting ethics was first conceptualized in terms of fidelity to the original. In Horace's classical phrase, the translator should be an interpres fides (see e.g. Kelly 1979). One of the most influential interpretations of this fidelity has been the requirement of "sameness": the translator should reproduce the "same" message, without changing it. This ethics of sameness was important in early Bible translation: literal translation was mandatory, in order not to risk altering the Word of God. This meant not just preserving the same message, but also the same form, as far as the language differences allowed. Compare the modern term "formal equivalence". The value underlying this ethics of sameness is truth: a translation may not be "untrue" to its source. As Newmark puts it (1991: 1), "[t]ranslation is concerned with moral and with factual truth".

However, the requirement of "sameness" between a fixed source text and its translation is not a universal value. In India, for instance, translators have played much more freely with classical Sanskrit texts, with much more fluid concepts of both 
text and translation. There have also been different views within the European tradition. The belles infidèles translations of the French Renaissance were in beautiful French, but seldom close to their originals. The Romantic period in Germany, on the other hand, introduced a new ethical position: an ethics of difference, of the Other. Schleiermacher (1813) argued that translations (of literary works) should not sound natural but overtly different, so that the reader would recognize the Other in the text. This awareness and reception of alterity has been taken to be an ethical act in itself (cf. Berman 1985: 86). Translations along these lines may be "hybrids" which allow the source text to be visible in some way in the translation (cf. Benjamin 1923), or they may just be as literal as possible. Scholars arguing for formally close translation tend to focus on literary and/or sacred texts, underlining the importance of listening to the formal patterns and rhythms of the original, as these form part of the expression of the overall textual meaning (e.g. Meschonnic 2007).

During the past thirty years or so, translation ethics has aroused a good deal of debate. This may be partly because the notions of sameness and the translator's invisibility have been increasingly problematized, and partly because of the growing sociological interest in translators and their agency, and issues of ideology, power, manipulation and responsibility.

Venuti $(1995,1998)$ and others have advocated a "foreignizing" translation strategy (other related terms are "minoritizing", "exoticizing", and "abusive fidelity"), resisting the stylistic norms of the target language and thus aiming to contribute to cultural change. Such a translation strategy rejects the idea that a translator should be transparent, invisible.

There have been several moves within Translation Studies to extend translation ethics beyond textual relations. Nord (1991) brought into skopos theory the concept of 
loyalty, denoting a moral principle of responsibility between people (translator, client, original author, reader...). Skopos theory, like other functional theories of translation, has implicitly adopted an ethics of service, prioritizing translator-client relations, efficient use of resources, the value of trust.

Pym's monograph $(1997,2012)$ offers an ethics of the translator, not of translation. For him, the role of such an ethics is a social one: to promote the process of translators' professionalization (1997: 101). He discusses the ethical issues concerning (literary) translators who are attacked or even killed for their translations: in what way are they responsible for what they write? He argues for the valuation of the intercultural spaces inhabited by translators, and for a deeper understanding of the translator's responsibility also to himself (e.g. decisions on what not to translate, and on not wasting one's own time and effort) and to the translators' profession. The ultimate justification for translation is the contribution it can make to intercultural cooperation, which in Pym's analysis is a fundamental guiding principle, although hard to define precisely.

Koskinen (2000) offers a critical analysis of both Venuti's and Pym's ethics, from a postmodern perspective. She problematizes the notion of fidelity, noting its many interpretations including the feminist one (2000: 19). Like both Venuti and Pym, she takes for granted that any translation ethics must encompass more than merely textual relations. Contributing to the discussion of the translator's visibility, she shows how visibility can be not only textual but also paratextual or extratextual (2000: 99).

Another development in the discussion of translation ethics has been the rise of "committed" or "interventionist" approaches. In these, the translator's personal ethics is given priority, together with the value of justice. Early examples were feminist 
translation ethics, and postcolonial views of translation. A growing contemporary focus is on "activist translation", such as that done by groups of volunteers (professionals or not) for causes having to do e.g. with social justice. An example is the Babels group, who work for the Social Forum movement.

Ethical issues can also be relevant to quality management. Abdallah (2012) has argued for a concept of quality that would include reference to translators' working conditions and client relations, because these can affect the responsibility which can be reasonably assigned to the translator.

Professional associations have set up codes of practice with stipulations concerning both obligations and working conditions. (For some examples, see References under AIIC and FIT.) These codes are mainly embedded in the ethics of sameness, mentioning such values as fidelity and impartiality, and do not seem to condone e.g. foreignizing or interventionist translation.

The traditional duty of interpreters to be neutral has been challenged e.g. by Inghilleri (2012), with special respect to community interpreting. She argues that, given the incommensurability of different languages, interpreters should be allowed to be guided more by their own personal ethics. Historical research on the role of translators and interpreters in wartime has further problematized the neutrality ideal, and also questioned the ethics of their treatment by clients. (See e.g. Footit and Kelly 2012.)

\section{An example}

To illustrate some of the complexity of a translator's ethical responsibility, consider the following case (discussed in more detail in Chesterman 2009). A literary 
translator, Stefan Moster, translates a Finnish novel by Arto Paasilinna into German. At one point in this fantastical story set in Finland's pagan past, a semi-divine hero is born, who will save Finland from the threat of the new Christian religion. The hero is born on April 20. But the German version says he is born on April 19. Why? Because April 20 was Hitler's birthday. Many German readers will know this, so there is a risk that the novel will be taken as neo-Nazi propaganda, and this is a risk the translator refuses to take. On his own responsibility, he changes the date. He informs the German publisher, but not the author. Asking the author's permission would have run the risk of being refused, and this risk too he did not wish to take. Later (Moster 2003), he makes the reasons for his decision public.

One can query Moster's textual solution (why not just "in the spring"?), but his decision to delete the original date can be respected. The ethical justification is utilitarian: possible undesirable consequences weigh more heavily than being true to the original, and also more heavily than consultation with the author. The translator has demonstrated loyalty to the publisher, and perhaps to the author on the understanding that there was no intention that the novel should have a Nazi undertone ( - most unlikely). By bringing the issue into public debate, Moster exploits the translator's extratextual visibility and highlights the responsibility of the professional. He has certainly not treated the text in a neutral way, but has intervened, in defence of his own ideology against an opposing one. Has he placed his personal ethics above his professional ones? No, if it is granted that he has acted professionally, in the wider interests of intercultural relations, of long-term cooperation. He is clearly concerned with more than merely textual relations.

The matter is made even more complex by a further twist. April 20 also happens to be the author's birthday. Not many Finnish readers would have known 
this, but it is quite likely that Paasilinna enjoyed this as a kind of in-joke. And Paasilinna himself may not have been aware that the day was also Hitler's birthday.

\section{Some open questions}

Translation is never entirely neutral or objective; there are always shifts, and the translator always leaves a mark, so the ideals of total sameness and impartial representation can never be achieved absolutely. Hence the importance of ethical awareness and responsibility. There is, however, little agreement on how far this responsibility should extend: are translators also professionally responsible for educating their clients? For demanding ethically acceptable working conditions? For working to increase the visibility of the profession? Are translators professionally responsible for working towards a fairer world? What is the best solution when personal and professional ethics clash? Are all-encompassing guidelines a realistic aim? And what about non-professionals, such as crowdsourced translators: what are their rights?

Claims about translation ethics, and professional codes of good practice, may assume universal validity; however, they are often conditioned by historical and cultural context, or pertain to particular text-types, such as the Bible, or literature, or non-literary texts. To what extent is generalization possible?

\section{References}

Abdallah, Kristiina. 2012. Translators in Production Networks. Reflections on agency, quality and ethics. Joensuu: Publications of the University of Eastern Finland. Available at: http://urn.fi/URN:ISBN:978-952-61-0609-0.

AIIC (International Association of Conference Interpreters), Code of Professional Ethics: http://aiic.net/page/6724 
Benjamin, Walter. [1923] 1963. "Die Aufgabe des Übersetzers". In Das Problem des Übersetzens, H. J. Störig (ed.), 182-195. Darmstadt: Wissenschaftliche Buchgesellschaft.

Berman, Antoine. 1985. "La traduction et la lettre - ou l'auberge du lointain". In Les Tours de Babel, A. Berman (ed.), 35-150. Mauvezin: Trans-Europ-Repress.

Chesterman, Andrew. 2009. "An ethical decision". In Translators and their readers. In homage to Eugene Nida. R. Dimitriu and M. Shlesinger (eds), 347-354. Brussels: Éditions du Hazard.

FIT (International Federation of Translators), Translator's Charter: http://www.fitift.org/?p=251

FIT Europe, European Code of Professional Practice: http://www.fiteurope.org/vault/deont/European Code \%20Professional Practice.pdf

Footit, Hilary, and Michael Kelly (eds). 2012. Languages at War. Policies and practices of language contacts in conflict. London: Palgrave Macmillan.

Inghilleri, Moira. 2012. Interpreting Justice. Ethics, politics and language. London: Routledge.

Kelly, Louis G. 1979. The True Interpreter. Oxford: Blackwell.

Koskinen, Kaisa. 2000. Beyond Ambivalence. Postmodernity and the ethics of translation. Tampere: University of Tampere.

Meschonnic, Henri. 2007. Ethique et politique du traduire. Paris: Verdier. (English translation 2011: Ethics and Politics of Translating. Trans. By Pier-Pascale Boulanger. Amsterdam/Philadelphia: John Benjamins.)

Moster, Stefan. 2003. "Birthday blues". Books from Finland 2003 (1): 59-60. Also available at <http://www.finlit.fi/booksfromfinland/bff/103/moster.html>

Newmark, Peter. 1991. About translation. Clevedon: Multilingual Matters.

Nord, Christiane. 1991. Text Analysis in Translation. Amsterdam/Atlanta: Rodopi.

Pym, Anthony. 1997. Pour une éthique du traducteur. Arras Presses Université. (English edition 2012: On Translator Ethics. Principles for mediation between cultures. Amsterdam/Philadelphia: John Benjamins.)

Schleiermacher, Friedrich. [1813] 1963. "Ueber die verschiedenen Methoden des Uebersezens". In Das Problem des Übersetzens, H. J. Störig (ed.), 38-70. Darmstadt: Wissenschaftliche Buchgesellschaft.

Venuti, Lawrence. 1995. The Translator's Invisibility: a history of translation. London/New York: Routledge.

Venuti, Lawrence. 1998. The Scandals of Translation: towards an ethics of difference. London/New York: Routledge.

\section{Further reading}

Baker, Mona. 2006. Translation and Conflict: A Narrative Account. London/New York: Routledge.

McDonough Dolmaya, Julie. 2011. "The Ethics of Crowdsourcing”. Linguistica Antverpiensia 10: 97-111.

The Translator. Special issues 2001, 7 (2), The Return to Ethics; 2012, 18 (2), Nonprofessionals Translating and Interpreting: participatory and engaged perspectives; and 2010, 16 (2), Translation and Violent Conflict. 